\title{
Article
}

\section{Growth and Antioxidant Responses in Iron-Biofortified Lentil under Cadmium Stress}

\author{
Ruchi Bansal ${ }^{1, *,+} \mathbb{0}$, Swati Priya ${ }^{1,+}{ }^{\text {, Harsh Kumar Dikshit }}{ }^{2, *} \mathbb{0}$, Sherry Rachel Jacob ${ }^{3}$, Mahesh Rao ${ }^{4} \mathbb{D}_{\text {, }}$ \\ Ram Swaroop Bana ${ }^{5}$, Jyoti Kumari ${ }^{1}$, Kuldeep Tripathi ${ }^{1}{ }^{1}$, Ashok Kumar ${ }^{1}$, Shiv Kumar ${ }^{6}(\mathbb{0}$ \\ and Kadambot H. M. Siddique ${ }^{7}$ (1)
}

check for

updates

Citation: Bansal, R.; Priya, S.; Dikshit, H.K.; Jacob, S.R.; Rao, M.; Bana, R.S.; Kumari, J.; Tripathi, K.; Kumar, A.; Kumar, S.; et al. Growth and Antioxidant Responses in Iron-Biofortified Lentil under Cadmium Stress. Toxics 2021, 9, 182. https://doi.org/10.3390/ toxics 9080182

Academic Editor: Ilektra Sperdouli

Received: 10 May 2021

Accepted: 7 July 2021

Published: 31 July 2021

Publisher's Note: MDPI stays neutral with regard to jurisdictional claims in published maps and institutional affiliations.

Copyright: (c) 2021 by the authors. Licensee MDPI, Basel, Switzerland. This article is an open access article distributed under the terms and conditions of the Creative Commons Attribution (CC BY) license (https:/ / creativecommons.org/licenses/by/ $4.0 /)$.
1 Division of Germplasm Evaluation, ICAR - National Bureau of Plant Genetic Resources, New Delhi 110012, India; swatipriya9013@gmail.com (S.P.); Jyoti.Kumari@icar.gov.in (J.K.); Kuldeep.Tripathi@icar.gov.in (K.T.); Ashok.Kumar28@icar.gov.in (A.K.)

2 Division of Genetics, ICAR - Indian Agricultural Research Institute, New Delhi 110012, India

3 Division of Germplasm Conservation, ICAR-National Bureau of Plant Genetic Resources, New Delhi 110012, India; Sherry.Jacob@icar.gov.in

4 ICAR_National Institute of Plant Biotechnology, New Delhi 110012, India; mraoiari@gmail.com

5 Division of Agronomy, ICAR-Indian Agricultural Research Institute, New Delhi 110012, India; rsbana@gmail.com

6 International Centre for Agricultural Research in Dryland Areas, Avenue Hafiane Cherkaoui, Rabat 10112, Morocco; SK.Agrawal@cgiar.org

7 The UWA Institute of Agriculture, The University of Western Australia, Perth, WA 6001, Australia; kadambot.siddique@uwa.edu.au

* Correspondence: Ruchi.Bansal@icar.gov.in (R.B.); harshgeneticsiari@gmail.com (H.K.D.)

+ Authors with equal contribution.

Abstract: Cadmium (Cd) is a hazardous heavy metal, toxic to our ecosystem even at low concentrations. Cd stress negatively affects plant growth and development by triggering oxidative stress. Limited information is available on the role of iron $(\mathrm{Fe})$ in ameliorating $\mathrm{Cd}$ stress tolerance in legumes. This study assessed the effect of Cd stress in two lentil (Lens culinaris Medik.) varieties differing in seed Fe concentration (L4717 (Fe-biofortified) and JL3) under controlled conditions. Six biochemical traits, five growth parameters, and Cd uptake were recorded at the seedling stage (21 days after sowing) in the studied genotypes grown under controlled conditions at two levels (100 $\mu \mathrm{M}$ and $200 \mu \mathrm{M})$ of cadmium chloride $\left(\mathrm{CdCl}_{2}\right)$. The studied traits revealed significant genotype, treatment, and genotype $\times$ treatment interactions. Cd-induced oxidative damage led to the accumulation of hydrogen peroxide $\left(\mathrm{H}_{2} \mathrm{O}_{2}\right)$ and malondialdehyde in both genotypes. JL3 accumulated $77.1 \%$ more $\mathrm{H}_{2} \mathrm{O}_{2}$ and $75 \%$ more lipid peroxidation products than L4717 at the high Cd level. Antioxidant enzyme activities increased in response to Cd stress, with significant genotype, treatment, and genotype $\times$ treatment interactions $(p<0.01)$. L4717 had remarkably higher catalase $(40.5 \%)$, peroxidase $(43.9 \%)$, superoxide dismutase (31.7\%), and glutathione reductase (47.3\%) activities than JL3 under high Cd conditions. In addition, L4717 sustained better growth in terms of fresh weight and dry weight than JL3 under stress. JL3 exhibited high Cd uptake (14.87 $\mathrm{mg} \mathrm{g}^{-1}$ fresh weight) compared to L4717 (7.32 $\mathrm{mg} \mathrm{g}^{-1}$ fresh weight). The study concluded that the Fe-biofortified lentil genotype L4717 exhibited Cd tolerance by inciting an efficient antioxidative response to $\mathrm{Cd}$ toxicity. Further studies are required to elucidate the possibility of seed Fe content as a surrogacy trait for Cd tolerance.

Keywords: antioxidant; cadmium; dry weight; heavy metal; iron; lentil

\section{Introduction}

Cadmium (Cd) stress is an important issue of global concern. This hazardous heavy metal enters the environment through various industrial and agricultural anthropogenic activities. It may pollute water or soil, and its accumulation in plants and animals poses serious threats to human health [1]. Since Cd is mobile and soluble in nature, it is easily 
taken up by plants. Its uptake adversely affects plant growth and development and causes toxicity symptoms, including necrotic lesions, stunted growth, and chlorosis [2]. Cd inhibits photosynthesis by retarding the rate of electron transport, chlorophyll fluorescence, stomatal conductance, and enzymatic reactions in carbon fixation [3]. Severe reductions in growth and yield of plants exposed to $\mathrm{Cd}$ toxicity have been documented in crops such as mung bean [4], tomato [5], rice [6], and wheat [7].

Studies on Cd uptake, transport, and accumulation have shown that $\mathrm{Cd}$ competes with other metals at their absorption sites, leading to their substitution and causing disbalance in metabolic activities [8]. Cd, a divalent cation, competes with iron $(\mathrm{Fe})$, magnesium $(\mathrm{Mg})$, and calcium $(\mathrm{Ca})$ during membrane transport. Fe deficiency was associated with $\mathrm{Cd}$ toxicity by Fe-dependent gene regulation in Arabidopsis $[9,10]$. Cd binds with the sulfhydryl groups of proteins and impairs protein function [11]. The cell's redox state subsequently changes, producing reactive oxygen species (ROS) in plants that can damage lipids, proteins, and other macromolecules, such as DNA and RNA. Different enzymatic and non-enzymatic antioxidants detoxify ROS to cope with oxidative damage. Upregulation of antioxidant activity in response to Cd-induced toxicity has been reported in wheat, rice, chickpea, and mung bean [12-15].

To mitigate Cd stress, application of nutrients such as Fe has been suggested for rice [16], wheat [7], and mung bean [4]. Ca and Fe enhanced the activity of various antioxidant enzymes in mung bean and chickpea, respectively, to ameliorate Cd stress $[4,13]$. In Fe-supplemented mung bean in a Cd-rich environment, shoot biomass had strong correlations with malondialdehyde, hydrogen peroxide $\left(\mathrm{H}_{2} \mathrm{O}_{2}\right)$, peroxidase, polyphenol oxidase, and glutathione reductase activities [4].

Studies on Cd stress responses are available primarily in cereals with the minimal information reported in legumes. Lentil (Lens culinaris Medik.) is an important legume crop cultivated worldwide as a source of dietary protein. Lentil has been biofortified with Fe and zinc $(\mathrm{Zn})$ to address micronutrient malnutrition. While some studies are available for various legumes on improving $\mathrm{Cd}$ tolerance by supplementing with $\mathrm{Fe}, \mathrm{Zn}$, and $\mathrm{Ca}$, no such information is available for lentil. Since Fe supplementation could improve Cd tolerance in legumes, we used Fe-biofortified lentil varieties for this study. We hypothesized that lentil varieties with high Fe content in the seed will ameliorate Cd stress. In this study, we evaluated the antioxidative and growth responses of two lentil varieties with differing seed Fe contents to Cd toxicity.

\section{Materials and Methods}

\subsection{Experimental Material and Treatments}

The experimental material comprised two lentil varieties, L4717 and JL3, released for Central India. L4717, also known as Pusa Ageti Masoor (Fe concentration 65 ppm), is a medium-sized seed, biofortified lentil variety developed at the Indian Agricultural Research Institute, New Delhi, India [17] and JL3 (Fe concentration 45 ppm) was developed at Jawaharlal Nehru Krishi Vishwavidyalaya, Jabalpur, Madhya Pradesh, India. The study was undertaken in controlled growth conditions in a polycarbonate house $\left(28-23^{\circ} \mathrm{C}\right.$ day /night temperatures and $75 \%$ relative humidity) at the Phenotyping facility, National Institute of Plant Biotechnology, New Delhi. Seeds were treated with 1\% sodium hypochlorite for 2-3 min, followed by washing with distilled water. The washed seeds were germinated on filter paper. Five-day-old seedlings were transferred in five replications to pots $(8 \mathrm{~cm}$ diameter) containing $500 \mathrm{~g}$ of soil. The field topsoil $(0-20 \mathrm{~cm}$ depth) was collected from the Research farm, Indian Agricultural Research Institute, New Delhi $\left(28.6410^{\circ} \mathrm{N}, 77.1539^{\circ} \mathrm{E}\right)$. The soil $\mathrm{pH}$ was 7.1, and nitrogen, potassium, and phosphorus contents were $62 \mathrm{~kg} \mathrm{ha}^{-1}$, $48 \mathrm{~kg} \mathrm{ha}^{-1}$, and $155 \mathrm{~kg} \mathrm{ha}^{-1}$, respectively. Seedlings were exposed to two cadmium chloride $\left(\mathrm{CdCl}_{2}\right)$ levels $(100 \mu \mathrm{M}$ and $200 \mu \mathrm{M})$ based on seedling survival in a standardization experiment carried out at different $\mathrm{Cd}$ concentrations (50-500 $\mu \mathrm{M})$. In the control, seedlings were irrigated with normal water as needed. Plants were harvested to record different biochemical and growth traits after 21 days of stress. 


\subsection{Determination of Biochemical Parameters}

Biochemical assays $\left(\mathrm{H}_{2} \mathrm{O}_{2}\right.$, lipid peroxidation, peroxidase, catalase, glutathione reductase, superoxide dismutase) were carried out on freshly harvested root samples.

To measure $\mathrm{H}_{2} \mathrm{O}_{2}$ content, $100 \mathrm{mg}$ of root tissue was homogenized in $1 \mathrm{~mL}$ of $0.1 \%(w / v)$ trichloroacetic acid followed by centrifugation at $12,000 \times g$ for $15 \mathrm{~min}$ [18]. The extract $(0.5 \mathrm{~mL})$ was mixed with $0.5 \mathrm{~mL}$ of $10 \mathrm{mM}$ potassium phosphate buffer ( $\mathrm{pH} 7.4)$ and $1 \mathrm{~mL}$ of $1 \mathrm{M}$ potassium iodide. Absorbance was read at $390 \mathrm{~nm}$, and $\mathrm{H}_{2} \mathrm{O}_{2}$ content calibrated using a standard curve.

Lipid peroxidation was recorded by measuring malondialdehyde (MDA) content in the form of thiobarbituric acid-reactive substances (TBARS) [19]. A $100 \mathrm{mg}$ root sample was extracted in $5 \%(w / v)$ trichloroacetic acid (TCA) and centrifuged at $10,000 \times g$ for $20 \mathrm{~min}$. The extract $(0.5 \mathrm{~mL})$ was mixed with $1 \mathrm{~mL}$ of $0.5 \%(w / v)$ thiobarbituric acid in $20 \%$ TCA. The reaction was carried out at $95^{\circ} \mathrm{C}$ for $20 \mathrm{~min}$, cooled immediately, and centrifuged again at $4000 \times \mathrm{g}$ for $10 \mathrm{~min}$. Absorbance was read at $532 \mathrm{~nm}$, and non-specific absorption was recorded at $600 \mathrm{~nm}$.

Peroxidase (POX, EC 1.11.1.7) activity was recorded spectrophotometrically [20]. The enzyme was extracted from $100 \mathrm{mg}$ of root tissue homogenized in $5 \mathrm{~mL}$ of $0.1 \mathrm{M}$ phosphate buffer ( $\mathrm{pH}$ 6.4). The reaction mixture $(5 \mathrm{~mL})$ contained $0.2 \mathrm{~mL}$ of supernatant, $50 \mu \mathrm{M}$ pyrogallol, $50 \mu \mathrm{M} \mathrm{H}_{2} \mathrm{O}_{2}$, and $0.1 \mathrm{M}$ phosphate buffer ( $\mathrm{pH}$ 6.4), which was incubated at $25^{\circ} \mathrm{C}$ for $5 \mathrm{~min}$. To terminate the reaction, $5 \% \mathrm{H}_{2} \mathrm{SO}_{4}$ was added, with absorbance recorded at $420 \mathrm{~nm}$. Enzyme activity was represented as enzyme unit (EU) and one unit was defined as the amount of enzyme that generates $1 \mathrm{~mol}$ purpurogallin per min in assay conditions.

To measure catalase (CAT, EC 1.11.1.6) activity, $100 \mathrm{mg}$ of root tissue was homogenized in $5 \mathrm{~mL}$ of $0.1 \mathrm{M}$ phosphate buffer ( $\mathrm{pH}$ 6.4) and centrifuged at $10,000 \times \mathrm{g}$ at $4{ }^{\circ} \mathrm{C}$ for $20 \mathrm{~min}$ using a refrigerated centrifuge. The reaction mixture comprised $2.6 \mathrm{~mL}$ of $0.1 \mathrm{M}$ phosphate buffer ( $\mathrm{pH}$ 6.4), $0.2 \mathrm{~mL}$ of supernatant, and $0.1 \mathrm{~mL}$ of $10 \mathrm{mM} \mathrm{H}_{2} \mathrm{O}_{2}$ [21]. Changes in absorbance at $230 \mathrm{~nm}$ were recorded using a microplate spectrophotometer. Enzyme activity was shown as EU calculated using $36 \mathrm{mM} \mathrm{cm}^{-1}$ as the extinction coefficient

Superoxide dismutase (SOD, EC1.15.1.1) activity was measured spectrophotometrically [22]. The enzyme was extracted by homogenizing $100 \mathrm{mg}$ of root tissue in $5 \mathrm{~mL}$ of $0.1 \mathrm{M}$ phosphate buffer ( $\mathrm{pH} 7.5)$. The reaction mixture $(3 \mathrm{~mL})$ contained $1.5 \mathrm{M}$ sodium carbonate, $200 \mathrm{mM}$ methionine, $2.25 \mathrm{mM}$ NBT, $0.3 \mathrm{mM}$ EDTA, $100 \mathrm{mM}$ potassium phosphate buffer, and $0.1 \mathrm{~mL}$ of enzyme extract. To start the reaction, $0.1 \mathrm{~mL}$ of riboflavin $(60 \mu \mathrm{M})$ was added, and absorbance was read at $560 \mathrm{~nm}$ in a spectrophotometer. One EU was defined as $50 \%$ inhibition of basic rate of reaction.

To measure glutathione peroxidase (GR, EC 1.6.4.2) activity, $100 \mathrm{mg}$ of root tissue was extracted in $5 \mathrm{~mL}$ of $0.5 \mathrm{M}$ potassium phosphate buffer ( $\mathrm{pH} 7$ ). The reaction was carried out with $50 \mathrm{mM}$ potassium phosphate buffer $(\mathrm{pH} 7)$, containing $10 \%(w / v)$ polyvinylpyrrolidone (PVP), $0.25 \%(v / v)$ Triton X-100, $1 \mathrm{mM}$ phenylmethylsulfonyl fluoride, $1 \mathrm{mM}$ dehydroascorbate reductase (DHAR, EC 1.8.5.1), and $1 \mathrm{mM}$ monodehydroascorbate reductase (MDHAR, EC 1.6.5.4) [23]. Absorbance was read at $340 \mathrm{~nm}$. The reduction in absorbance due to oxidation of NADPH into NADP during the reaction indicated enzyme activity shown as EU.

\subsection{Determination of Growth Parameters and Cd Content}

Total biomass (fresh weight, FW and dry weight, DW), total length (TL), shoot length (SL), and root length (RL) were recorded after harvesting 21-day-old seedlings. TL, SL, and RL were measured using a long ruler. FW was recorded immediately after harvest, and DW was recorded for all samples after oven drying at $65^{\circ} \mathrm{C}$ for $48 \mathrm{~h}$. To measure $\mathrm{Cd}$ content, dried plants were ground and digested using concentrated nitric acid [24]. Cd content was quantified using an atomic absorption spectrometer. 


\subsection{Statistical Analysis}

Data analysis was carried out using SPSS version 16.0 with five replicates for each treatment. Significant differences among all factors were measured using analysis of variance (ANOVA) and the least significant difference. Significant differences were estimated at $p<0.05$ and $p<0.01$. Pearson's correlation coefficients were calculated using mean values of both the genotypes for the recorded traits under stress conditions.

\section{Results}

The ANOVA revealed that the recorded biochemical and growth parameters significantly differed for treatments, genotypes, and their interaction.

\subsection{Effect of $C d$ on Biochemical Parameters}

Increasing $\mathrm{Cd}$ concentration increased $\mathrm{H}_{2} \mathrm{O}_{2}$ content and lipid peroxidation in both lentil genotypes, indicating stress-mediated oxidative injury (Figure 1A,B). At $100 \mu \mathrm{M}$, L4717 accumulated $27.2 \%$ more $\mathrm{H}_{2} \mathrm{O}_{2}$ than JL3, while at higher $\mathrm{Cd}(200 \mu \mathrm{M})$, JL3 significantly increased $\mathrm{H}_{2} \mathrm{O}_{2}$ content; genotype, treatment, and interaction effects were significant at $p<0.01$ (Table 1 ).
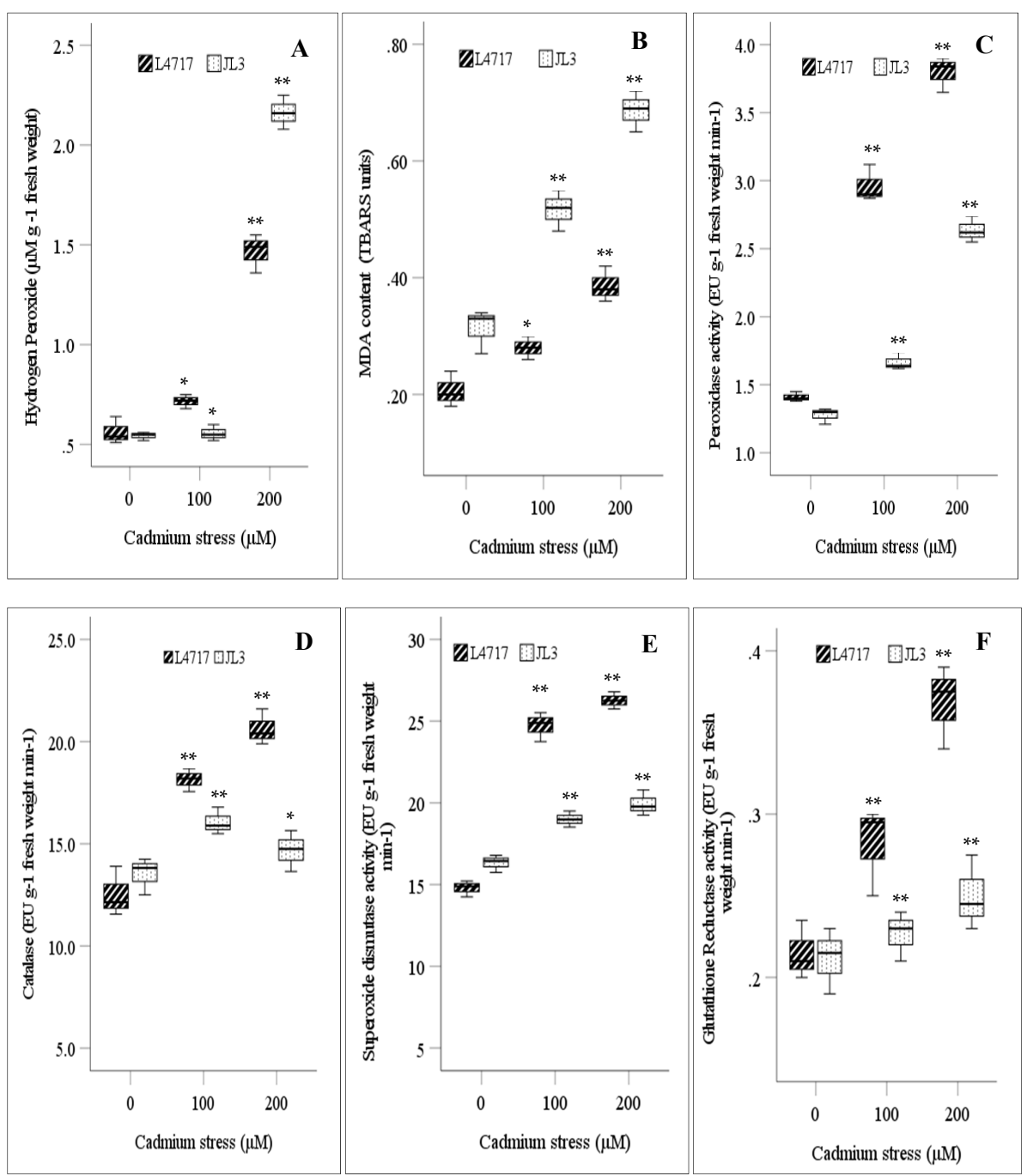

Figure 1. Changes in (A) hydrogen peroxide, (B) malondialdehyde, (C) peroxidase, (D) catalase, (E) superoxide dismutase, and (F) glutathione reductase activity in lentil seedlings under Cd stress. The central bar in each box represents the median, and each box shows the interquartile range. * and ** indicate significant differences among treatments at $p<0.05$ and $p<0.01$, respectively. 
Table 1. Analysis of variance (ANOVA) F values for biochemical traits between lentil genotypes, Cd treatments, and their interaction.

\begin{tabular}{ccccccc}
\hline Source of Variation & HP & MDA & POX & CAT & SOD & GR \\
\hline Treatment & $728.59^{* *}$ & $111.71^{* *}$ & $587.71^{* *}$ & $47.55^{* *}$ & $238.04^{* *}$ & $28.63^{* *}$ \\
Genotype & $32.55^{* *}$ & $201.35^{* *}$ & $374.29^{* *}$ & $30.75^{* *}$ & $133.79^{* *}$ & $32.19^{* *}$ \\
Treatment $\times$ Genotype & $77^{* *}$ & $14.16^{* *}$ & $67.68^{* *}$ & $22.47^{* *}$ & $69.76^{* *}$ & $10.27^{* *}$ \\
\hline
\end{tabular}

* Significant at $p<0.05,{ }^{* *}$ significant at $p<0.01$; HP: hydrogen peroxide; MDA: malondialdehyde; POX: peroxidase; CAT: catalase; SOD: superoxide dismutase; GR: glutathione reductase.

JL3 had significantly higher MDA contents than L4717 in both Cd treatments (Figure 1B). At $100 \mu \mathrm{M} \mathrm{Cd}$, MDA content increased by $64.9 \%$ in JL3 and $35.5 \%$ in L4717, relative to the controls. At $200 \mu \mathrm{M} \mathrm{Cd}$, MDA content increased by $87 \%$ in $\mathrm{L} 4717$ and $119 \%$ in JL3, relative to the controls. The $\mathrm{F}$ values revealed significant differences for treatment, genotype, and their interaction $(p<0.01)$ (Table 1$)$.

Significant differences $(p<0.01)$ occurred for treatment, genotype, and their interaction for all measured enzymes (POX, CAT, SOD, and GR) (Table 1). Mean POX activity increased by $72.3 \%$ at $100 \mu \mathrm{M} \mathrm{Cd}$ and $139.5 \%$ at $200 \mu \mathrm{M} \mathrm{Cd}$. POX activity in L4717 increased by more than two and three times at $100 \mu \mathrm{M}$ and $200 \mu \mathrm{M} \mathrm{Cd}$, respectively, relative to the controls (Figure 1C).

CAT activity also increased significantly in response to Cd stress (Figure 1D), more so in L4717 than JL3. CAT activity increased by $44.7 \%$ in L4717 and $18.8 \%$ in JL3 at $100 \mu \mathrm{M}$ Cd. At $200 \mu \mathrm{M} \mathrm{Cd}$, CAT activity increased by $64.6 \%$ in L4717 but decreased slightly in JL3.

L4717 increased SOD activity more than JL3 in both Cd treatments (Figure 1E). No significant differences in SOD activity occurred in JL3 at $100 \mu \mathrm{M}$ or $200 \mu \mathrm{M} \mathrm{Cd}$, relative to the control. In L4717, SOD activity increased by $67.2 \%$ at $100 \mu \mathrm{M} \mathrm{Cd}$ and $77.6 \%$ at $200 \mu \mathrm{M} \mathrm{Cd}$.

Similarly, GR activity increased by $31 \%$ in L4717 but not in JL3 at $100 \mu \mathrm{M} \mathrm{Cd}$ and by $71.3 \%$ in L4717 and $22.1 \%$ in JL3 at $200 \mu \mathrm{M} \mathrm{Cd}$ (Figure 1F).

\subsection{Effect of Cd Stress on Seedling Growth}

The measured growth parameters (TL, SL, RL, FW, DW, and Cd content) significantly decreased in response to Cd stress (Table 2).

Table 2. ANOVA of F values for growth traits and Cd uptake between lentil genotypes, Cd treatments, and their interaction.

\begin{tabular}{ccccccc}
\hline Source of Variation & TL & RL & SL & FW & DW & CdC \\
\hline Treatment & $94.93^{* *}$ & $9.21^{* *}$ & $58.86^{* *}$ & $368.26^{* *}$ & $45.80^{* *}$ & $3483.91^{* *}$ \\
Genotype & $144.04^{* *}$ & $84.88^{* *}$ & $88.54^{* *}$ & $98.37^{* *}$ & $64.80^{* *}$ & $871.36^{* *}$ \\
Treatment $\times$ Genotype & $21.32^{* *}$ & $3.85^{*}$ & $2.52^{*}$ & $3.86^{*}$ & $2.90^{*}$ & $430.83^{* *}$ \\
\hline
\end{tabular}

${ }^{*}$ Significant at $p<0.05,{ }^{* *}$ significant at $p<0.01$, TL: total length, RL: root length, SL: shoot length, FW: fresh weight, DW: dry weight, CdC:

Cd content.

The genotypic mean for TL declined by $22.7 \%$ at $100 \mu \mathrm{M} \mathrm{Cd}$ and $40.8 \%$ at $200 \mu \mathrm{M} \mathrm{Cd}$. At $100 \mu \mathrm{M} \mathrm{Cd}$, TL decreased by $8.5 \%$ in L4717 and 38\% in JL3; at $200 \mu \mathrm{M} \mathrm{Cd}$, TL decreased by $21.4 \%$ in L4717 and $61.7 \%$ in JL3 (Figure 2A). Genotype, treatment, and their interaction for TL differed significantly at $p<0.01$ (Table 2 ). 

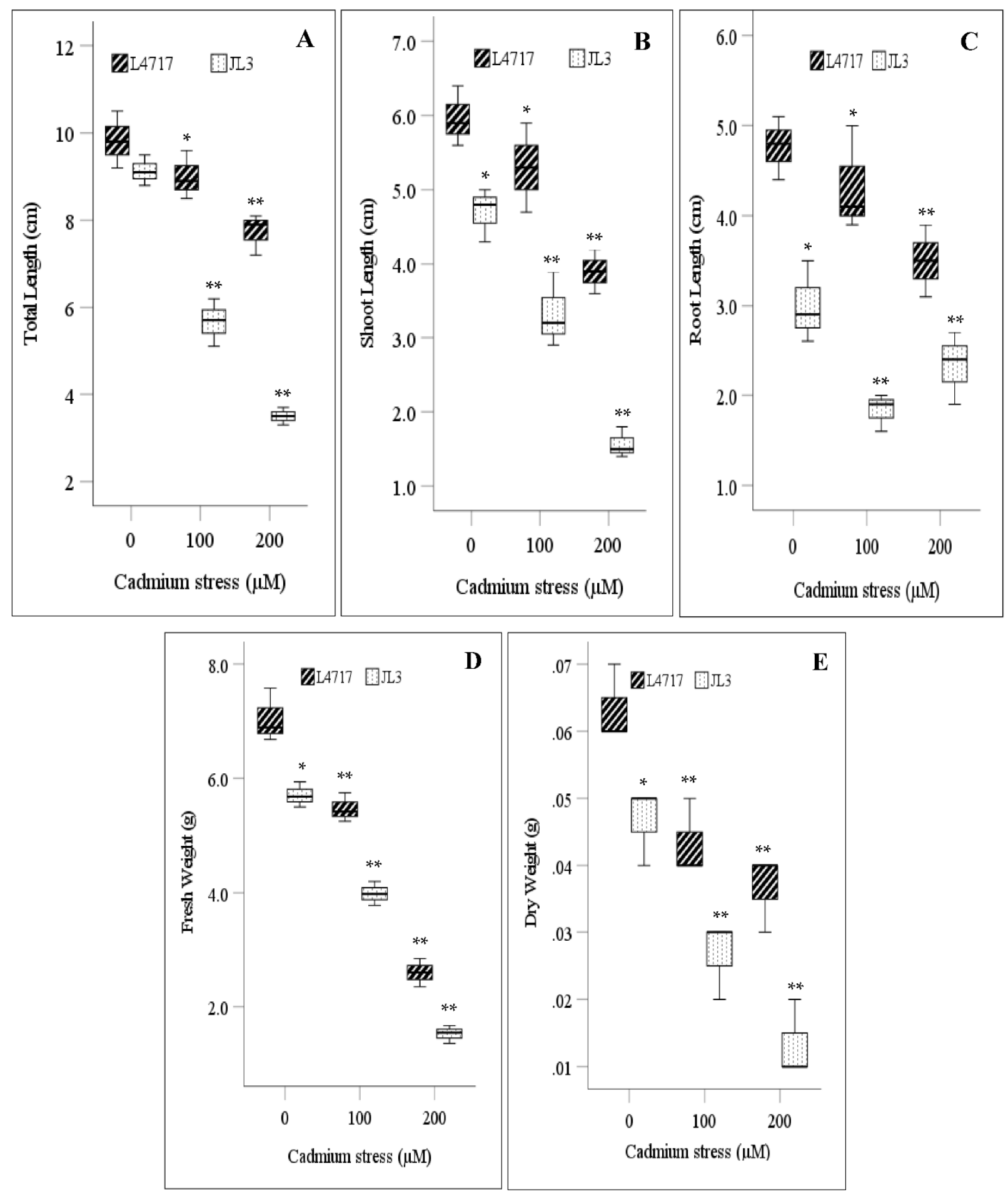

Figure 2. Changes in (A) total length, (B) shoot length, (C) root length, (D) fresh weight, and (E) dry weight of lentil seedlings under $\mathrm{Cd}$ stress. The central bar in each box represents the median, and each box shows the interquartile range. * and ${ }^{* *}$ indicate significant differences among treatments at $p<0.05$ and $p<0.01$, respectively.

The genotypic means for SL and RL declined by $19.1 \%$ and $2.7 \%$ at $100 \mu \mathrm{M} \mathrm{Cd}$, and $48.8 \%$ and $2.7 \%$ at $200 \mu \mathrm{M} \mathrm{Cd}$, respectively. Genotype and treatment differences were significant for both traits at $p<0.01$, while their interaction was significant at $p<0.05$ (Table 2). SL and RL declined more in JL3 than L4717 in both Cd treatments (Figure 2B,C). For L4717, RL declined more at $100 \mu \mathrm{M}$ Cd than $200 \mu \mathrm{M}$ Cd; for JL3, RL declined with increasing Cd level. SL decreased in both genotypes with increasing $\mathrm{Cd}$ level. 
Total biomass (FW and DW) declined significantly in both genotypes under Cd stress (Figure 2D,E). Genotype and treatment differences were significant at $p<0.01$, while their interaction was significant at $p<0.05$ (Table 2). The genotypic mean for FW and DW declined by $25.8 \%$ and $37.2 \%$ at $100 \mu \mathrm{M} \mathrm{Cd}$ and $54.1 \%$ and $60.2 \%$ at $200 \mu \mathrm{M} \mathrm{Cd}$, respectively. FW declined more in JL3 than L4717 (73.3\% vs. $49.6 \%)$, relative to the controls under high Cd conditions (Figure 2D). DW declined by $36.8 \%$ in L4717 and $71.4 \%$ in JL3 at $200 \mu \mathrm{M}$ $\mathrm{Cd}$ (Figure 2E).

\subsection{Cd Uptake}

Significant differences $(p<0.01)$ in total $\mathrm{Cd}$ accumulation occurred for genotype, treatment, and their interaction (Table 2). JL3 had greater Cd uptake than L4717 in both Cd treatments-42.1\% higher at $100 \mu \mathrm{M} \mathrm{Cd}$ and $103.2 \%$ higher at $200 \mu \mathrm{M} \mathrm{Cd}$ (Figure 3).

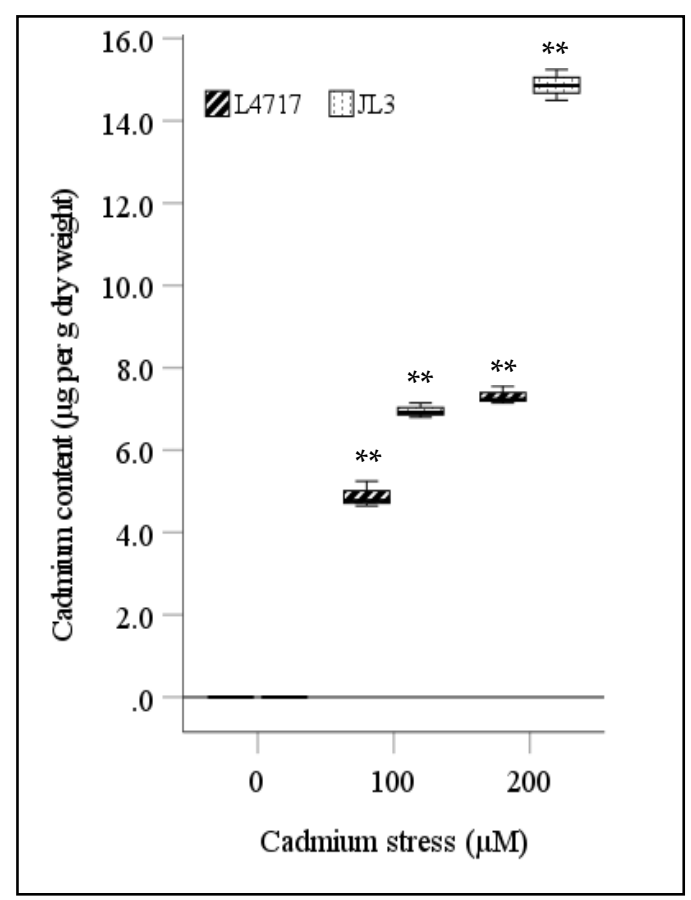

Figure 3. Cd uptake in lentil seedlings under Cd stress. The central bar in each box represents the median, and each box shows the interquartile range. ${ }^{*}$ and ${ }^{* *}$ indicate significant differences among treatments at $p<0.05$ and $p<0.01$, respectively.

\subsection{Pearson's Correlations Analysis to Cd Stress}

Pearson's correlations were undertaken to determine the relationship between different biochemical and growth traits in lentils under Cd stress (Figure 4). FW and DW had positive correlations with TL, SL, and RL. Various growth traits (FW, DW, TL, SL, and RL) had significant negative correlations with oxidative injuries $\left(\mathrm{H}_{2} \mathrm{O}_{2}\right.$ and MDA contents). Significant negative correlations occurred between DW and $\mathrm{H}_{2} \mathrm{O}_{2}(\mathrm{r}=-0.66)$, MDA $(r=-0.93)$ and $\mathrm{Cd}$ content $(\mathrm{r}=-0.87)$. Cd uptake had positive correlations with $\mathrm{H}_{2} \mathrm{O}_{2}(\mathrm{r}=0.86)$ and MDA $(\mathrm{r}=0.89)$ and a negative correlation with POX activity $(\mathrm{r}=-0.54)$. Significant positive correlations were recorded between $\mathrm{H}_{2} \mathrm{O}_{2}$ and MDA $(r=0.72)$ and $\mathrm{H}_{2} \mathrm{O}_{2}$ and POX activity $(\mathrm{r}=0.60)$. Significant positive correlations also occurred between the activities of POX and CAT $(r=0.85)$, SOD and POX $(r=0.93)$, GR and POX $(r=0.90)$, and SOD and GR $(r=0.88)$, but enzyme activities did not significantly correlate with growth parameters. 


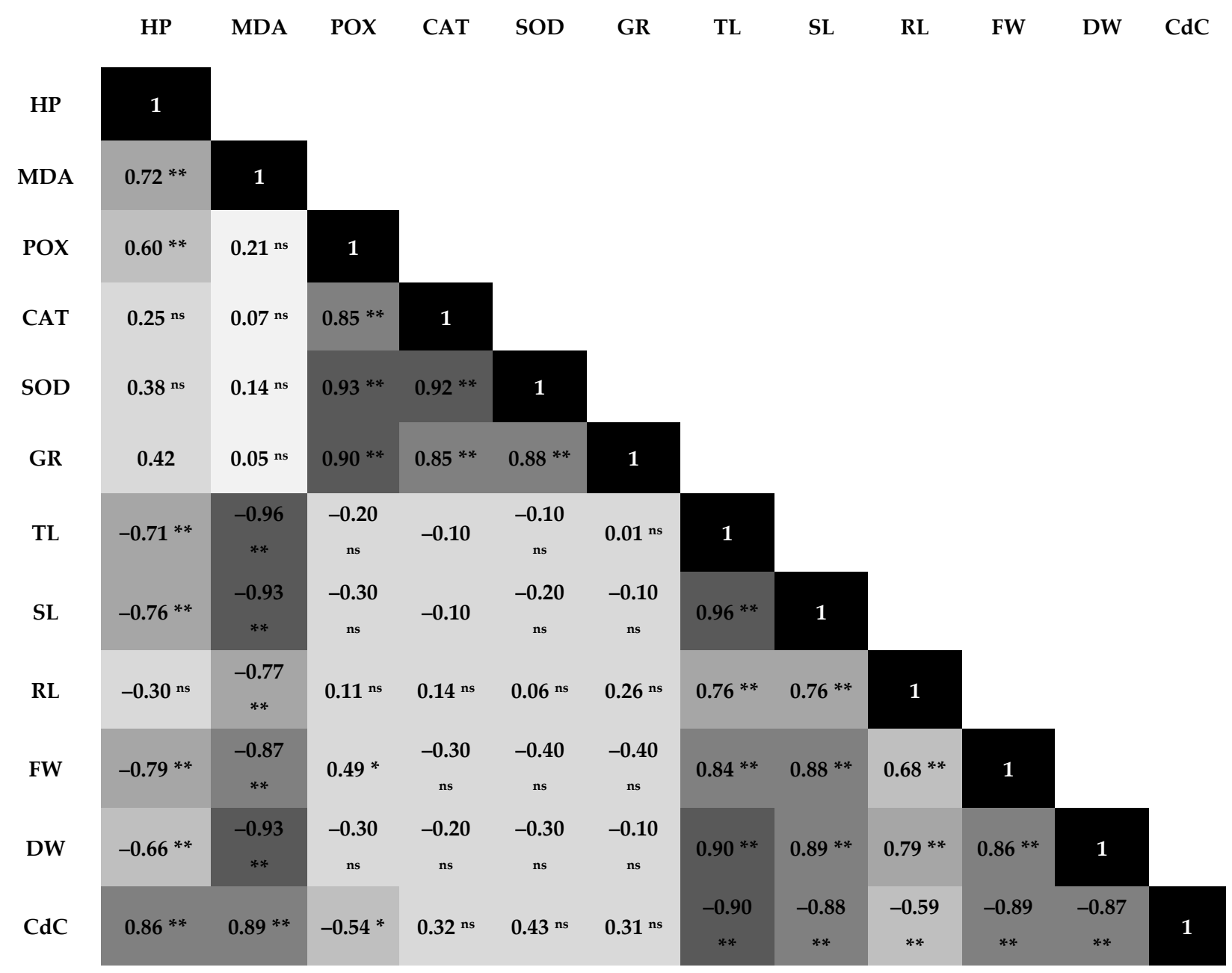

Figure 4. Correlation matrix of different traits under Cd-rich conditions, ${ }^{\text {ns }}$ non-significant, ${ }^{*}$ significant at $p<0.05$, ${ }^{* *}$ significant at $p<0.01$. HP: hydrogen peroxide, MDA: malondialdehyde, POX: peroxidase, CAT: catalase, SOD: superoxide dismutase, GR: glutathione reductase, TL: total length, SL: shoot length, RL: root length, FW: fresh weight, DW: dry weight, $\mathrm{CdC}$ : Cd content. Color intensity increases with increasing correlations between traits.

\section{Discussion}

Studies have shown that $\mathrm{Cd}$ toxicity inhibits plant growth and development, adversely affecting physiological mechanisms, including germination, photosynthesis, ion transport, and mineral nutrition, resulting in reduced biomass and yield in different crops [25-27]. $\mathrm{Cd}$ is easily transported into plants, entering different metabolic pathways by substituting the metals present at the binding site or binding with different proteins, making them inactive. Cd changes the redox environment, implying metabolic disturbances. The generation of high concentrations of ROS is the source of plant oxidative stress in Cdrich environments [28]. High ROS concentrations are detrimental to membrane structure and lipid and protein function; the extent of injury depends on the species and stress intensity $[13,27]$.

Our study showed significant modulation of ROS-scavenging activities in lentil roots in response to $\mathrm{Cd}$ stress. Roots are the prime organ responsible for $\mathrm{Cd}$ uptake in plants. $\mathrm{Cd}$ is transported to shoots and other tissues after sequestration into vacuoles, translocation into xylem and phloem, and dilution through shoot growth. Root ultrastructure and antioxidative activities are important for stress tolerance in pea under Cd stress [29].

The stress-induced injury was apparent in both genotypes as $\mathrm{H}_{2} \mathrm{O}_{2}$ and MDA contents increased in both $\mathrm{Cd}$ treatments, though JL3 had higher susceptibility to $\mathrm{Cd}$ stress than L4717 (Figure 1A,B). Similar findings have been reported in mung bean [4], chickpea [13], 
and faba bean [26]. JL3 had greater oxidative damage than L4717, evident by greater accumulation of $\mathrm{H}_{2} \mathrm{O}_{2}$ and lipid peroxidation products in the presence of $\mathrm{Cd}$. While $\mathrm{H}_{2} \mathrm{O}_{2}$ is a stable molecule with a comparatively long half-life relative to other ROS, it can trigger damage if it moves across the membrane. CAT and POX activities are critical for catalyzing the dissociation of $\mathrm{H}_{2} \mathrm{O}_{2}$, with POX having a higher affinity for $\mathrm{H}_{2} \mathrm{O}_{2}$ than CAT. L4717 had higher CAT and POX activities than JL3 in the presence of $100 \mu \mathrm{M}$ and $200 \mu \mathrm{M} \mathrm{Cd}$ (Figure $1 \mathrm{C}, \mathrm{D}$ ), indicating that $\mathrm{L} 4717$ is more efficient at $\mathrm{H}_{2} \mathrm{O}_{2}$ degradation than JL3. Elevated enzymatic activities may be associated with excessive $\mathrm{H}_{2} \mathrm{O}_{2}$ generation as observed in Cd-stressed plants [14]. Genes encoding CAT were upregulated in plants exposed to heavy metal stress [30]. However, the increase in POX and CAT activities under $\mathrm{Cd}$ stress was insufficient to remove $\mathrm{H}_{2} \mathrm{O}_{2}$, and therefore, it accumulated in L4717 and JL3.

SOD is a key enzyme, which dismutates superoxide radicals into $\mathrm{H}_{2} \mathrm{O}_{2}$ and $\mathrm{O}_{2}$. SOD activity was significantly upregulated in $\mathrm{L} 4717$ in the presence of $\mathrm{Cd}$, but declined in JL3 (Figure 1E). Differences in SOD activity demonstrate the dearth of antioxidant capacity in JL3 to cope with Cd-induced oxidative stress. Hence, MDA accumulation increased in JL3 under stress (Figure 1B). The higher SOD activity in L4717 was ascribed to its high seed Fe concentration (65 ppm) compared to JL3 (45 ppm). The low availability of Fe chelates in JL3 leads to a low level of SOD activity, as reported for barley [31]. GR is the enzyme responsible for reducing oxidized glutathione in a reduced form, and NADPH is required for GR activity. GR is responsible for maintaining reduced glutathione levels by $\mathrm{H}_{2} \mathrm{O}_{2}$ elimination. L4717 had significantly higher GR activity than JL3 under both Cd levels (Figure $1 \mathrm{~F}$ ), which enhanced its stress tolerance and ability to eliminate $\mathrm{H}_{2} \mathrm{O}_{2}$. Cd stressmediated increases in GR activity were also reported in mung bean [4] and chickpea [13].

Heavy metal tolerance improved in chickpea as $\mathrm{H}_{2} \mathrm{O}_{2}$ content and cell membrane injury declined with exogenous $\mathrm{Ca}$ and $\mathrm{K}$ treatments [13]. Fe supplementation improved the oxidative response in mung bean by modulating enzyme activities in Cd-enriched conditions [4]. Growth of low seed Fe genotype JL3 declined more in both $\mathrm{Cd}$ treatments due to notable oxidative injuries and high $\mathrm{Cd}$ uptake, despite increased antioxidant activities in both the genotypes (Figures 1-3). This study showed that lentil genotypes acclimatized to Cd stress by exerting strong antioxidant activities, with POX being the key player in $\mathrm{H}_{2} \mathrm{O}_{2}$ detoxification. The higher antioxidant capacity of L4717 suggests that Fe-rich genotypes can alleviate $\mathrm{Cd}$ toxicity more effectively than genotypes with low seed Fe concentration. Fe supplementation improved $\mathrm{Cd}$ tolerance in mung bean [4] and rice [32] by maintaining chlorophyll content and modulating redox status and Cd uptake. It was proposed that Fe-rich conditions ensure Fe availability, a ligand for different antioxidant enzymes, and a binding force for forming multi-protein complexes [12].

All measured growth traits (TL, SL, RL, FW, and DW) decreased significantly in lentils exposed to Cd stress (Table 2), and more so in JL3 than L4717 (Figure 2). Plant weight and TL had negative correlations with oxidative injury indicators under Cd stress (Figure 4). JL3 had significant injuries and stunted growth, indicating its high susceptibility to Cd stress. JL3 also had higher Cd uptake than L4717 under Cd stress (Figure 3). Cd content had negative correlations with all measured growth traits, but Fe-rich L4717 sustained growth better than JL3. As reported in mung bean and rice, Fe supplementation was associated with less $\mathrm{Cd}$ accumulation under stress through modulated transporter activities [4,12]. We also observed that Fe-biofortified L4717 accumulated less Cd than JL3. Fe is a co-factor of antioxidase, which protects against $\mathrm{Cd}$ toxicity [33]. No significant correlations were recorded between growth traits and enzymatic activities in lentils, except for a positive correlation between FW and POX activity, indicating that POX is the key enzyme contributing to $\mathrm{Cd}$ tolerance in lentils (Figure 4). In mung bean and chickpea, GR activity was highly correlated with Cd stress tolerance [4,12,13].

In summary, this study revealed that $\mathrm{Cd}$ stress significantly affects lentil growth by oxidative damage. Cd stress tolerance in biofortified L4717 was attributed to strong antioxidant potential and improved growth in toxic environments due to high seed Fe content. We suggest that the biofortification of lentil varieties may help reduce malnutrition 
and improve $\mathrm{Cd}$ tolerance. The role of foliar application of Fe should be studied in lentil varieties to improve $\mathrm{Cd}$ tolerance. Using high Fe content as a surrogate tool for $\mathrm{Cd}$ tolerance in lentils and other legume crops needs to be explored.

Author Contributions: Conceptualization: R.B., S.P. and H.K.D.; methodology: R.B. and S.P.; formal analysis: R.B.; resources: H.K.D., M.R., R.S.B., S.R.J. and S.K.; writing—original draft preparation: R.B. and H.K.D.; writing - review and editing: R.S.B., J.K., K.T., A.K., S.K. and K.H.M.S.; supervision: S.K. and K.H.M.S. All authors have read and agreed to the published version of the manuscript.

Funding: The work was supported by Indian Council of Agricultural Research (ICAR) and CGIAR Research Program on Grain legumes \& Dryland Cereals (GLDC) and funded by CGIAR Fund Donors.

Acknowledgments: The authors acknowledge the Director, ICAR-National Bureau of Plant Genetic Resources, New Delhi, the Director, ICAR-Indian Agricultural Research Institute, New Delhi, and the Director, ICAR-National Institute of Plant Biotechnology, New Delhi for providing the facilities to carry out the study.

Conflicts of Interest: The authors declare no conflict of interests.

\section{References}

1. Bolan, N.S.; Adriano, D.C.; Mani, P.; Duraisamy, A.; Arulmozhiselvan, S. Immobilization and phytoavailability of Cd in variable charge soils: I. Effect of phosphate addition. Plant Soil 2003, 250, 83-94. [CrossRef]

2. Choppala, G.; Ullah, S.; Bolan, N.; Bib, S.; Iqbal, M.; Rengel, Z.; Kunhikrishnan, A.; Ashwath, N.; Ok, Y.S. Cellular mechanisms in higher plants governing tolerance to Cd toxicity. Crit. Rev. Plant. Sci. 2004, 33, 374-391. [CrossRef]

3. Paunov, M.; Koleva, L.; Vassilev, A.; Vangronsveld, J.I.D.; Goltsev, V. Effects of different metals on photosynthesis: Cd and zinc affect chlorophyll fluorescence in durum wheat. Int. J. Mol. Sci. 2018, 19, 787. [CrossRef] [PubMed]

4. Biyani, K.; Tripathi, D.K.; Lee, J.H.; Muneer, S. Dynamic role of iron supply in amelioration of Cd stress by modulating antioxidative pathways and peroxidase enzymes in mungbean. AoB Plants 2019, 11, plz005. [CrossRef]

5. Rahmatizadeh, R.; Arvin, S.M.J.; Jamei, R.; Mozaffari, H.; Nejhad, F.R. Response of tomato plants to interaction effects of magnetic $\left(\mathrm{Fe}_{3} \mathrm{O}_{4}\right)$ nanoparticles and Cd stress. J. Plant Interact. 2019, 14, 474-481. [CrossRef]

6. Hussain, B.; Ashraf, M.N.; Rahman, S.U.; Abbas, A.; Li, J.; Farooq, M. Cd stress in paddy fields: Effects of soil conditions and remediation strategies. Sci. Total Environ. 2021, 754, 142188. [CrossRef] [PubMed]

7. Adrees, M.; Khan, Z.; Ali, S.; Hafeez, M.; Khalid, S.; Zia-ur-Rehman, M.; Hussain, A.; Hussain, K.; Chatha, S.A.S.; Rizwan, M. Simultaneous mitigation of $\mathrm{Cd}$ and drought stress in wheat by soil application of iron nanoparticles. Chemosphere 2020, 238, 124681. [CrossRef]

8. Nazar, R.; Iqbal, N.; Masood, A.; Khan, R.; Khan, N. Cd toxicity in plants and role of mineral nutrients in its alleviation. Am. J. Plant Sci. 2012, 3, 1476-1489. [CrossRef]

9. Hermans, C.; Chen, J.; Coppens, F.; Inzé, D.; Verbruggen, N. Low magnesium status in plants enhances tolerance to Cd exposure. New Phytol. 2011, 192, 428-436. [CrossRef]

10. Lešková, A.; Giehl, R.F.H.; Hartmann, A.; Fargašová, A.; Wirén, N.V. Heavy metals induce iron deficiency responses at different hierarchic and regulatory levels. Plant Physiol. 2017, 174, 1648-1668. [CrossRef]

11. Hasan, S.A.; Fariduddin, Q.; Ali, B.; Hayat, S.; Ahmad, A. Cd: Toxicity and tolerance in plants. J. Environ. Biol. $2009,30,165-174$. [PubMed]

12. Muneer, S.; Kim, T.H.; Qureshi, M.I. Fe modulates Cd-induced oxidative stress and the expression of stress response proteins in the nodules of mungbean. Plant Growth Regul. 2012, 68, 421-433. [CrossRef]

13. Ahmad, P.; Abdel Latef, A.A.; Abid Allah, E.F.; Hashem, A.; Sarwat, M.; Anjum, N.A.; Gucel, S. Calcium and potassium supplementation enhanced growth, osmolyte secondary metabolite production, and enzymatic antioxidant machinery in Cdexposed chickpea (Cicer arietinum L.). Front. Plant Sci. 2016, 7, 513-520. [CrossRef]

14. Li, Y.; Wang, L.; Yang, L.; Li, H. Dynamics of rhizosphere properties and antioxidative responses in wheat (Triticum aestivum L.) under Cd stress. Ecotoxicol. Environ. Saf. 2014, 102, 55-61. [CrossRef] [PubMed]

15. Srivastava, R.K.; Pandey, P.; Rajpoot, R.; Rani, A.; Dubey, R.S. Cd and lead interactive effects on oxidative stress and antioxidative responses in rice seedlings. Protoplasma 2014, 251, 1047-1065. [CrossRef]

16. Sebastian, A.; Prasad, M.N.V. Iron-and manganese-assisted Cd tolerance in Oryza sativa L.: Lowering of rhizotoxicity next to functional photosynthesis. Planta 2015, 241, 1519-1528. [CrossRef] [PubMed]

17. Yadava, D.K.; Hussain, F.; Mohapatra, T. Nutritional security through crop biofortification in India: Status and future prospects. Indian J. Med. Res. 2018, 148, 621-631.

18. Velikova, V.; Yordanova, I.; Edreva, A. Oxidative stress and some antioxidant systems in acid rain-treated bean plants: Protective role of exogenous polyamines. Plant Sci. 2000, 151, 59-66. [CrossRef]

19. Heath, R.L.; Packer, L. Photoperoxidation in isolated chloroplasts. I. Kinetics and stoichiometry of fatty acid peroxidation. Arch. Biochem. Biophys. 1968, 125, 189-198. [CrossRef] 
20. Kar, M.; Mishra, D. Catalase, peroxidase and polyphenoloxidase activities during rice leaf senescence. Plant Physiol. 1976, 57, 315-319. [CrossRef]

21. Aebi, H.E. Catalase. In Methods in Enzymatic Analysis; Bergmeyer, U.S., Ed.; Verlag Chemie: Weinheim, Germany, 1983; Volume 1, pp. 273-286.

22. Dhindsa, R.; Plumb-Dhindsa, P.; Thorpe, T.A. Leaf senescence correlated with increased level of membrane permeability, lipid peroxidation and decreased level of SOD and CAT. J. Exp. Bot. 1981, 32, 93-101. [CrossRef]

23. Rao, M.V. Cellular detoxification mechanisms to determine age dependent injury in tropical plant exposed to $\mathrm{SO}_{2}$. J. Plant Physiol. 1992, 140, 733-740. [CrossRef]

24. Alexander, P.D.; Alloway, B.J.; Dourado, A.M. Genotypic variations in the accumulation of $\mathrm{Cd}, \mathrm{Cu}, \mathrm{Pb}$ and $\mathrm{Zn}$ exhibited by six commonly grown vegetables. Environ. Pollut. 2006, 144, 736-745. [CrossRef] [PubMed]

25. Mobin, M.; Khan, N.A. Photosynthetic activity, pigment composition and antioxidative response of two mustard (Brassica juncea) cultivars differing in photosynthetic capacity subjected to Cd stress. J. Plant Physiol. 2007, 164, 601-610. [CrossRef] [PubMed]

26. Siddiqui, M.H.; Al-Wahabi, M.; Sakran, A.; Basalah, M.; Ali, H. Effect of calcium and potassium on antioxidant system of Vicia faba L. under Cd stress. Int. J. Mol. Sci. 2012, 13, 6604-6619. [CrossRef]

27. Muneer, S.; Kim, T.H.; Choi, B.C.; Lee, B.S.; Lee, J.H. Effect of CO, NOx and $\mathrm{SO}_{2}$ on ROS production, photosynthesis and ascorbate-glutathione pathway to induce fragaria $\times$ annasa as a hyperaccumulator. Redox Biol. 2014, 2, 91-98. [CrossRef] [PubMed]

28. Romero-Puertas, M.C.; Corpas, F.J.; Rodriguez-Serrano, M.; Gomez, M.; Del Rio, L.A.; Sandalio, L.M. Differential expression and regulation of antioxidative enzymes by Cd in pea plants. J. Plant Physiol. 2007, 164, 1346-1357. [CrossRef]

29. Głowacka, K.; Źróbek-Sokolnik, A.; Okorski, A.; Najdzion, J. The effect of cadmium on the activity of stress-related enzymes and the ultrastructure of pea roots. Plants 2019, 8, 413. [CrossRef] [PubMed]

30. Qureshi, M.I.; Qadir, S.; Zolla, L. Proteomics-based dissection of stress-responsive pathways in plants. J. Plant Physiol. 2007, 164, 1239-1260. [CrossRef]

31. Astolfi, S.; Zuchi, S.; Hubberten, H.M.; Pinton, R.; Hoefgen, R. Supply of sulphur to S-deficient young barley seedlings restores their capability to cope with iron shortage. J. Exp. Bot. 2010, 61, 799-806. [CrossRef]

32. Shao, G.; Chen, M.; Wang, W.; Mou, R.; Zhang, G. Iron nutrition affects Cd accumulation and toxicity in rice plants. Plant Growth Regul. 2007, 53, 33-42. [CrossRef]

33. Sharma, S.S.; Kaul, S.; Metwally, A.; Goyal, K.C.; Finkemeier, I.; Dietz, K.J. Cd toxicity to barley (Hordeum vulgare) as affected by varying Fe nutritional status. Plant Sci. 2004, 166, 1287-1295. [CrossRef] 